\title{
Fermentation profile and microbial population in soybean silages with inoculant and powdered molasses
}

[Perfil fermentativo e população microbiana em silagens de soja com inoculante e melaço em pó]

\author{
L.O. Rosa' ${ }^{1}$, O.G. Pereira ${ }^{2}$, K.G. Ribeiro ${ }^{2}$, S.C. Valadares Filho ${ }^{2}$, P.R. Cecon ${ }^{2}$ \\ ${ }^{1}$ Aluna de pós-graduação - Universidade Federal de Viçosa - Viçosa, MG \\ ${ }^{2}$ Universidade Federal de Viçosa - Viçosa, MG
}

\begin{abstract}
Fermentation profile and microbial population were assessed in soybean silages without any additive (control), with inoculant (I), with I + powdered molasses (I+M), and with powdered molasses only (M). Soybean plants were harvested at the R6 stage and ensiled in $2 \mathrm{~kg}$-capacity laboratory silos. The additives were added to the natural matter base of silages. The assessed fermentation periods were 1, 3, 7, 14, 28, and 56 days. A $4 \times 6$ factorial arrangement ( 4 additives $\times 6$ fermentation periods) in a completely randomized design with 3 replicates was used. Lactic, acetic, and butyric acids concentrations were influenced by additives and periods $(\mathrm{P}<0.05)$. It was observed higher lactic acid values to control silages, on the $56^{\text {th }}$ day. Lower average values of acetic and butyric acids were observed to $\mathrm{I}+\mathrm{M}$ and $\mathrm{M}$ silages. It was observed quadratic effect to $\mathrm{pH}$ values with a reduction estimated of $0.5504,0.5358,0.6312$ and 0.6680 units to $\mathrm{pH}$ values to control, I, I+M, and $\mathrm{M}$ silages in the first 10 days. A maximum lactic acid bacteria population was observed at the $28^{\text {th }}$ day of fermentation in silages with inoculant. The inoculant and powdered molasses improve the fermentation profile of soybean silages.
\end{abstract}

Keywords: acid lactic bacteria, additives, fermentation, $\mathrm{pH}$

\section{RESUMO}

Avaliou-se o perfil fermentativo e a composição microbiana de silagens de soja sem aditivos (controle), com inoculante (I), com I + melaço em pó $(I+M)$ e com melaço em pó $(M)$. As plantas de soja foram colhidas no estádio R6 e ensiladas em silos laboratoriais com capacidade de $2 \mathrm{~kg}$. Os aditivos foram adicionados às silagens na matéria natural. Os períodos de fermentação avaliados foram: 1, 3, 7, 14, 28 e 56 dias. Utilizou-se um esquema fatorial $4 \times 6$ (quatro aditivos $\times$ seis períodos), em um delineamento completamente ao acaso, com três repetições. Observou-se efeito de aditivos e de período $(P<0,05)$ sobre os ácidos láctico, acético e butírico. Foi constatado maior teor de ácido láctico na silagem controle aos 56 dias. Para os teores dos ácidos acético e butírico, registraram-se menores valores médios nas silagens I+M e M. Observou-se efeito quadrático para o pH das silagens, com estimativa de redução de pH nos primeiros 10 dias igual a 0,5504; 0,5358; 0,6312 e 0,6680 nas silagens controle, I, I+M e M, respectivamente. A máxima população de bactéria ácido-láctica foi observada aos 28 dias nas silagens inoculadas. $O$ inoculante e o melaço em pó melhoram o perfil fermentativo de silagens de soja.

Palavras-chave: aditivo, bactéria ácido-láctica, fermentação, $\mathrm{pH}$

\section{INTRODUCTION}

Brazil is the second largest soybean producer in the world. In the soybean harvest in thousand fifteen and two thousand sixteen, national soybean production reached 95.43 million tons,

Recebido em 7 de outubro de 2016

Aceito em 9 de abril de 2018

E-mail: e-mail: lilianorosa@yahoo.com.br in a planted area of 33.25 million hectares with yields of $2,870 \mathrm{~kg} \mathrm{ha}^{-1}$ (CONAB, 2016). In this sense, considering the importance of this plant in Brazil, studies involving its use in animal feed science are justified because the soybean grain is an essential component in the manufacture of rations for the high protein content (MAPA, 
2013). Allied to this, the culture of soybean can also be used in the production of silage with good quality due to its great availability in the country.

From a historic perspective, legume plants were always rated as inadequate for ensiling because they exhibited a high buffer capacity as well as low water soluble carbohydrates and dry matter content. Besides these fermentation-restrictive characteristics inherent to legume plants, soybean further exhibits high ether extract content, which might inhibit bacteria in the ensiled mass; this inhibition affects fermentation, resulting in high silage $\mathrm{pH}$. Moreover, soybean has a low autochthonous population of lactic acid-producing bacteria (Pereira et al., 2007).

Soybean harvest for ensiling might be performed between stages R3 (onset of pod formation) and R7 (onset of maturity; Undersanden et al., 2007). However, Muñoz et al. (1983) recommended the R6 stage (full seed) as the most appropriate for soybean harvest due to the nutritional features (high protein value and high digestibility of dry matter) associated with high production of dry matter. Even at this developmental stage, however, the water-soluble carbohydrates content required for an appropriate fermentation is low (Blount et al., 2006). Therefore, the addition of an immediately fermentable sugar source, such as molasses, and, or the use of microbial inoculants could contribute to adequate fermentation when soybeans are ensiled alone (Pereira et al., 2007; Pereira et al., 2008).

Research on soybean silage is still incipient in Brazil despite the increasing demand for information by local farmers. Therefore, this study aimed at assessing the chemical composition, fermentation profile, and microbial populations of soybean silages treated with microbial inoculant and, or powdered molasses.

\section{MATERIAL AND METHODS}

Soybean plants were grown at the Department of Animal Science of the Federal University of Viçosa, located in Viçosa County, Minas Gerais (200 45' S, 420 51' W), Brazil in 2007 and the trials was conducted between 2007 and 2009.

The DM 339 (Pioneer) soybean variety was sown in November $26^{\text {th }} 2006$ in an $800-\mathrm{m}^{2}$ area, with 0.7-m spacing between rows and 25 to 30 seeds $\mathrm{m}^{-1}$ of sowing density. Soybean plants were hand-harvested using knives when they reached the R6 stage.

After the harvest, the material was cut in a stationary ensiling machine, and additives were applied before ensiling. The treatments were no additive (control), microbial inoculant (I), inoculant and powdered molasses (I+M), and powdered molasses only (M). The inoculant used was SIL ALL C4 (Alltech Brazil, composition: cellulosic enzymes, Pediococcus acidilactici, Lactobacillus plantarum, Enterococcus faecium, and $80 \%$ dextrose. The guaranteed levels of microorganisms were 10 billion CFU $\mathrm{g}^{-1} L$. plantarum, 1 billion CFU g ${ }^{-1} P$. acidilactici, and 10 billon CFU g ${ }^{-1}$ E. Faecium). Following the manufacturer recommendations, 5-g of inoculant in 1 ton of forage was applied using a 2-L capacity spray, and $2.5 \%$ powdered molasses was added to the natural base matter.

After the application of additives, ensiling was performed in PVC silos, with a diameter of $10 \mathrm{~cm}$ and height of $50 \mathrm{~cm}$ that included a Bunsen valve for gas release. In each silo was placed $2-\mathrm{kg}$ of fresh forage.

A $4 \times 6$ ( 4 additives $\times 6$ fermentation periods $)$ factorial scheme was used in a completely randomized design with 3 replicates.

Silos were opened after each fermentation period (1, 3, 7, 14, 28, and 56 days). At each fermentation period, a 25 -g silage sample was collected from each silo to determine the $\mathrm{pH}$ and ammonia nitrogen (ammonia-N) according to the method described by Bolsen et al. (1992).

The water-soluble carbohydrates contents in silages was evaluated according to the method described by Silva and Queiroz (2002).

To estimate the amount of organic acids, approximately $10-\mathrm{g}$ of fresh silage was diluted in $90 \mathrm{~mL}$ of distilled water and then homogenized in an industrial blender for 1 minute. The resulting aqueous extract was filtered through filter paper, and $1 \mathrm{~mL}$ of a $20 \%$ met phosphoric acid solution and $0.2 \mathrm{~mL}$ of phenic acid were added to $2 \mathrm{~mL}$ of the filtered extract; then, this combined solution was centrifuged according to the method described by Ranjit and Kung Jr. (2000). The 
determination of lactic, acetic, and butyric acids was performed using high performance liquid chromatography of Shimadzu-BIORAD mark, SPD-10 model, C18 column, reverse phase at a wavelength of $210 \mathrm{~nm}$.

At each fermentation period, a 10-g mixed silage sample was collected from 3 replicates of each treatment to quantified the microbial populations in silage and forage before ensiling using culture media specific for each microbial group, i.e., Rogosa agar (Difco) to quantify lactic acid bacteria (LAB; plates were incubated at $37^{\circ} \mathrm{C}$ for 48 hours); violet red bile agar (Difco) to assess enterobacteria (ENT; plates were incubated at $30^{\circ} \mathrm{C}$ for 24-48 hours); RCM (reinforced clostridia medium; Difco) to evaluate the presence of clostridia (cultures were incubated at $37^{\circ} \mathrm{C}$ for 48 hours); and potato dextrose agar (PDA) acidified with $10 \%$ tartaric acid to assess molds and yeasts (MY; cultures were incubated at $25^{\circ} \mathrm{C}$ for 3-6 days). The microbial populations' quantification was performed according to Santos (2011): ninety milliliters of phosphate buffer solution was added to a 10-g silage sample to obtain a dilution of $10^{-1}$, then serial dilutions were performed to obtain dilutions ranging from $10^{-1}$ to $10^{-9}$, and cultures were performed in duplicate using sterile Petri dishes.

Data on ammonia-N (\%total nitrogen) and content of organic acids were subject to variance and regression analyses using SAEG-UFV (2007) and the means were compared by Tukey test $0.05 \%$. To assess $\mathrm{pH}$ as a function of the fermentation period, data were adjusted to the following non-linear model suggested by Hristov and McAllister (2002): $\mathrm{Yt}=\mathrm{A}+\mathrm{B} \cdot \mathrm{e}^{\mathrm{-ct}}$, where $\mathrm{Yt}$ represents the final $\mathrm{pH}$ value; $\mathrm{A}$ represents the $\mathrm{pH}$ estimated value at the 56th day of fermentation; $\mathrm{B}$ represents the total fall in $\mathrm{t}$ tending to infinite; and $\mathrm{c}$ represents the decline rate of fraction $B$.

\section{RESULTS}

The $\mathrm{pH}$ and microbial composition of soybean plants before ensiling are describes in Table 1. It was observed quadratic effect to $\mathrm{pH}$ values with a reduction estimated of $0.5504,0.5358,0.6312$ and 0.6680 units to $\mathrm{pH}$ values in control, I, I+M, and $\mathrm{M}$ silages in the first 10 days.

Table 1. $\mathrm{pH}$ and microbial populations in soybean plants before ensiling

\begin{tabular}{ccccc}
\hline \multirow{2}{*}{ Item } & \multicolumn{5}{c}{ Forages } \\
\cline { 2 - 5 } & Control & I & I + M & M \\
\hline pH & 6.42 & 6.35 & 6.29 & 6.32 \\
WSC $^{1}$ & 76.7 & 77.1 & 81.1 & 78.9 \\
EAB $^{1}$ & 4.10 & -- & -- & - \\
CNT $^{1}$ & 5.08 & -- & -- & -- \\
MY $^{1}$ & 5.10 & -- & -- & -- \\
\hline
\end{tabular}

${ }^{1} \log$ CFU g ${ }^{-1},{ }^{2} \mathrm{~g} \mathrm{~kg}^{-1}$ of DM.

Control: Soybean plant without any additive, I: with a microbial inoculant, I+M: with I + powdered molasses and M: with powdered molasses.

WSC: water-soluble carbohydrates, LAB: lactic acid bacteria, ENT: enterobacteria, CL: clostridia and MY: molds and yeasts.

The average values of ammonia nitrogen (ammonia-N) and organic acids in the assessed soybean silages are describes in Table 2. An effect of the additive and fermentation periods was observed for all variables $(\mathrm{P}<0.05)$, but this effect was not constant. On the $56^{\text {th }}$ day of fermentation, higher ammonia-N values were found in control and I silages; the latter did not differ among it $(\mathrm{P}>0.05)$ and on the other hand less ammonia- $\mathrm{N}$ values were found in $\mathrm{I}+\mathrm{M}$ and
M silages $(\mathrm{P}<0.05)$ with not differ among it $(\mathrm{P}>$ $0.05)$.

Additionally, on the $56^{\text {th }}$ day of fermentation, in the control silages were observed higher values of lactic, acetic and butyric acids contents $(\mathrm{P}<$ $0.05)$. The soybean silages were average values to lactic acid/acetic acid ratio, equal 2.94; 3.50; 4.01 and 5.70 regarding to control, I, I+M and M silages. 
Table 2. Average contents of ammonia nitrogen ( $\mathrm{g} \mathrm{kg}^{-1}$ of total nitrogen) and lactic, acetic, and butyric acids ( $\mathrm{g} \mathrm{kg}^{-1}$ of dry matter) in soybean silages as a function of additives $(\mathrm{A})$ and fermentation periods (P)

\begin{tabular}{|c|c|c|c|c|c|c|c|c|c|c|c|}
\hline \multirow{3}{*}{ Additives } & \multicolumn{7}{|c|}{ Fermentation periods (days) } & \multicolumn{3}{|c|}{ Effect } & \multirow{2}{*}{$\begin{array}{c}\text { Standard } \\
\text { error }\end{array}$} \\
\hline & 1 & 3 & 7 & 14 & 28 & 56 & Mean & $\mathrm{A}$ & $\mathrm{P}$ & $\mathrm{AXP}$ & \\
\hline & \multicolumn{7}{|c|}{ Ammonia-N ( $\mathrm{g} \mathrm{kg}^{-1}$ of $\left.\mathrm{TN}\right)$} & $*$ & $*$ & ns & 6.96 \\
\hline Control & $34.3 \mathrm{a}$ & $50.9 \mathrm{a}$ & $60.8 \mathrm{a}$ & $88.7 \mathrm{ab}$ & $74.7 \mathrm{a}$ & $125.8 \mathrm{a}$ & 72.5 & & & & \\
\hline $\mathrm{I}$ & $34.9 \mathrm{a}$ & $51.9 \mathrm{a}$ & $67.1 \mathrm{a}$ & $79.0 \mathrm{ab}$ & $87.8 \mathrm{a}$ & $122.5 \mathrm{a}$ & 73.8 & & & & \\
\hline $\mathrm{I}+\mathrm{M}$ & $31.1 \mathrm{a}$ & $44.1 \mathrm{a}$ & $47.7 \mathrm{a}$ & $71.4 \mathrm{ab}$ & $61.9 \mathrm{a}$ & $59.4 b$ & 52.6 & & & & \\
\hline \multirow[t]{2}{*}{ M } & $31.3 \mathrm{a}$ & $41.6 \mathrm{a}$ & $46.2 \mathrm{a}$ & $56.0 \mathrm{~b}$ & $69.0 \mathrm{a}$ & $76.7 \mathrm{~b}$ & 53.4 & & & & \\
\hline & \multicolumn{7}{|c|}{ Lactic acid $\left(\mathrm{g} \mathrm{kg}^{-1}\right.$ of DM) } & $*$ & $*$ & ns & 1.28 \\
\hline Control & $14.8 \mathrm{~d}$ & $28.8 b$ & $28.1 b$ & $38.5 \mathrm{a}$ & $43.5 \mathrm{a}$ & $47.7 \mathrm{a}$ & 33.5 & & & & \\
\hline I & $19.9 \mathrm{c}$ & $25.5 \mathrm{c}$ & $31.7 \mathrm{a}$ & $34.5 b c$ & 42.0ab & $46.3 \mathrm{ab}$ & 33.3 & & & & \\
\hline $\mathrm{I}+\mathrm{M}$ & $22.5 b$ & $26.4 \mathrm{c}$ & $33.4 \mathrm{a}$ & $37.3 \mathrm{ab}$ & $41.0 \mathrm{~b}$ & $44.2 \mathrm{bc}$ & 34.1 & & & & \\
\hline \multirow[t]{2}{*}{ M } & $24.9 \mathrm{a}$ & $35.9 \mathrm{a}$ & $32.7 \mathrm{a}$ & $35.4 \mathrm{bc}$ & $36.8 \mathrm{c}$ & $43.0 \mathrm{c}$ & 34.8 & & & & \\
\hline & \multicolumn{7}{|c|}{ Acetic acid $\left(\mathrm{g} \mathrm{kg}^{-1}\right.$ of DM) } & $*$ & $*$ & ns & 0.71 \\
\hline Control & $6.6 \mathrm{a}$ & $7.0 \mathrm{a}$ & $14.3 \mathrm{a}$ & $11.3 \mathrm{a}$ & $12.5 \mathrm{a}$ & $16.6 \mathrm{a}$ & 11.4 & & & & \\
\hline $\mathrm{I}$ & $4.9 b$ & $7.2 \mathrm{a}$ & $8.8 \mathrm{c}$ & $10.2 \mathrm{a}$ & $12.0 \mathrm{a}$ & $14.3 \mathrm{~b}$ & 9.5 & & & & \\
\hline $\mathrm{I}+\mathrm{M}$ & $4.5 \mathrm{bc}$ & $5.1 b$ & $10.8 b$ & $8.8 b$ & $9.4 b$ & $12.3 \mathrm{c}$ & 8.5 & & & & \\
\hline \multirow[t]{2}{*}{ M } & $3.3 \mathrm{c}$ & $5.3 b$ & $5.8 \mathrm{~d}$ & $6.6 \mathrm{c}$ & $8.5 b$ & $7.5 \mathrm{~d}$ & 6.1 & & & & \\
\hline & \multicolumn{7}{|c|}{ Butyric acid ( $\mathrm{g} \mathrm{kg}^{-1}$ of DM) } & $*$ & $*$ & ns & 0.014 \\
\hline Control & $0.3 \mathrm{a}$ & $0.4 \mathrm{a}$ & $0.4 \mathrm{a}$ & $0.4 \mathrm{a}$ & $0.4 \mathrm{a}$ & $0.7 \mathrm{a}$ & 0.4 & & & & \\
\hline I & $0.2 b$ & $0.3 b$ & $0.3 b$ & $0.2 b$ & $0.3 b$ & $0.3 b$ & 0.3 & & & & \\
\hline $\mathrm{I}+\mathrm{M}$ & $0.2 \mathrm{~b}$ & $0.2 \mathrm{c}$ & $0.2 \mathrm{c}$ & $0.2 b$ & $0.2 b$ & $0.3 b$ & 0.2 & & & & \\
\hline M & $0.1 \mathrm{c}$ & $0.2 \mathrm{c}$ & $0.1 \mathrm{c}$ & $0.1 \mathrm{c}$ & $0.3 b$ & $0.4 b$ & 0.2 & & & & \\
\hline
\end{tabular}

Control: soybean silage without any additive, I: with a microbial inoculant, I+M: with I + powdered molasses and M: with powdered molasses.

AXP: interaction between additives (A) and fermentation periods (P).

*significant at a $5 \%$ level of significance.

ns: non-significant at a 5\% level of significance.

Same letters in the same column do not differ according to a Tukey test at a $5 \%$ level of significance.

The silage $\mathrm{pH}$ variation as a function of the fermentation period is represented in Figure 1. The estimated $\mathrm{pH}$ values of control, I, I+M, and $\mathrm{M}$ silages at the 56th fermentation day were 4.44, $4.49,4.33$, and 4.32 , respectively. In the first 10 days of fermentation was observed a reduction estimated of $0.5504,0.5358,0.6312$ and 0.6680 units to $\mathrm{pH}$ values in control, I, I+M, and $\mathrm{M}$ silages. Besides this, it was observed between $11^{\text {th }}$ and $56^{\text {th }}$ days of fermentation a reduction estimated in $0.01842,0.01154,0.02316$ and
0.01521 units to $\mathrm{pH}$ values in control, I, I+M, and $\mathrm{M}$ silages.

The populations of lactic acid bacteria (LAB), enterobacteria (ENT), clostridia (CL) and moulds and yeasts (MY) in soybean silages assessed at different fermentation periods are described in Table 3. The Table 3 contents the average values to microbial populations quantified in soybean silages evaluated. 


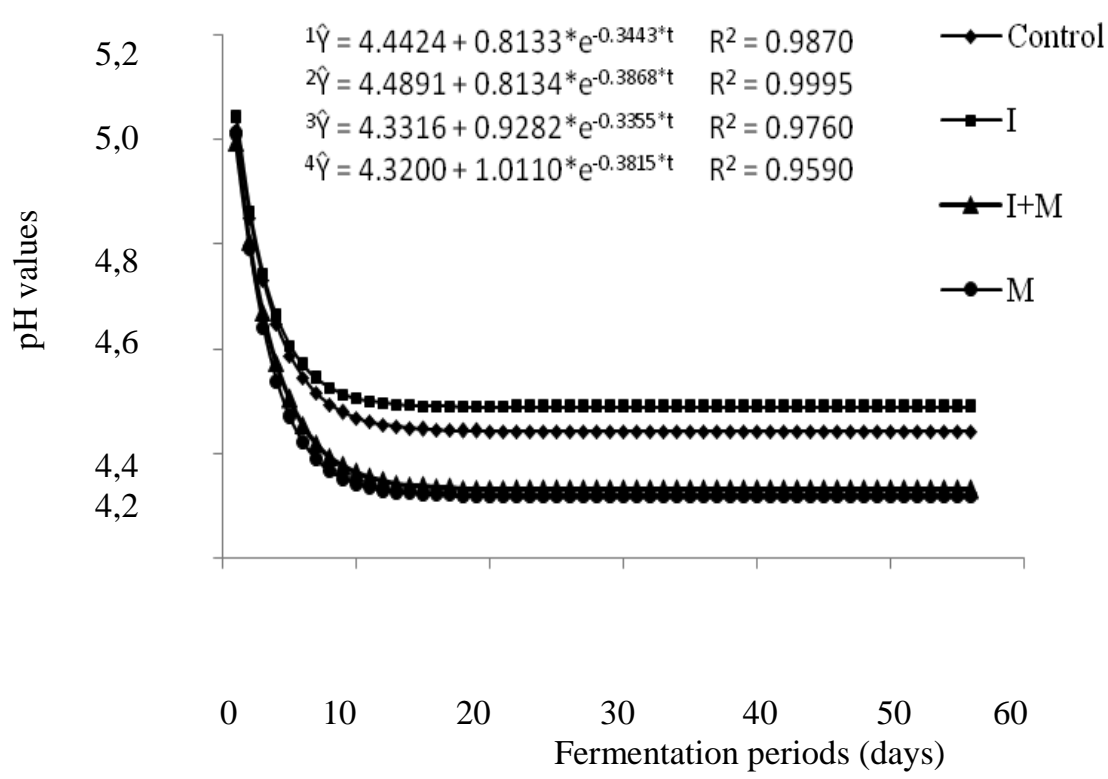

Figure 1. Variation of $\mathrm{pH}$ in soybean silages as a function of fermentation periods using different additives.

Control: soybean silage without any additive, I: with a microbial inoculant, I+M: with I + powdered molasses and M: with powdered molasses.

Table 3. Microbial populations in soybean silages as a function of additives and fermentation periods

\begin{tabular}{|c|c|c|c|c|c|c|c|}
\hline \multirow{3}{*}{ Silages } & \multicolumn{6}{|c|}{ Fermentation periods (days) } & \multirow[b]{3}{*}{ Mean } \\
\hline & 1 & 3 & 7 & 14 & 28 & 56 & \\
\hline & \multicolumn{5}{|c|}{ LAB $\left(\log C F U g^{-1}\right)$} & & \\
\hline Control & 7.35 & 8.11 & 8.52 & 8.95 & 9.04 & 8.87 & 8.47 \\
\hline I & 7.64 & 8.62 & 8.93 & 9.10 & 9.15 & 8.24 & 8.61 \\
\hline $\mathrm{I}+\mathrm{M}$ & 7.77 & 8.56 & 8.94 & 8.62 & 7.87 & 8.18 & 8.32 \\
\hline M & 7.72 & 8.48 & 8.58 & 8.62 & 7.05 & 8.28 & 8.12 \\
\hline \multicolumn{8}{|c|}{ ENT $\left(\log\right.$ CFU g $\left.^{-1}\right)$} \\
\hline Control & 5.40 & 4.63 & nd & nd & nd & nd & \\
\hline I & 4.43 & nd & nd & nd & nd & nd & \\
\hline $\mathrm{I}+\mathrm{M}$ & 4.22 & nd & nd & nd & nd & nd & \\
\hline M & 5.23 & 3.02 & nd & nd & nd & nd & \\
\hline \multicolumn{8}{|c|}{$\mathrm{CL}\left(\log \mathrm{CFU} \mathrm{g}{ }^{-1}\right)$} \\
\hline Control & 3.02 & nd & nd & nd & nd & nd & \\
\hline I & 2.45 & nd & nd & nd & nd & nd & \\
\hline $\mathrm{I}+\mathrm{M}$ & nd & nd & nd & nd & nd & nd & \\
\hline M & nd & nd & nd & nd & nd & nd & \\
\hline \multicolumn{8}{|c|}{$\mathrm{MY}\left(\log \mathrm{CFU} \mathrm{g}^{-1}\right)$} \\
\hline Control & 4.36 & 3.98 & 3.71 & 3.75 & 3.08 & 3.15 & 3.67 \\
\hline I & 3.48 & 3.00 & 2.94 & 3.15 & 2.95 & 3.10 & 3.10 \\
\hline $\mathrm{I}+\mathrm{M}$ & 3.32 & 2.97 & 2.89 & 3.20 & 3.40 & 4.22 & 3.33 \\
\hline M & 3.66 & 3.51 & 3.50 & 4.42 & 3.82 & 4.09 & 3.83 \\
\hline
\end{tabular}

Control: Soybean silage without any additive, I: with a microbial inoculant, I+M: with I + powdered molasses and M: with powdered molasses.

LAB: lactic acid bacteria, ENT: enter bacteria, CL: clostridia and MY: moulds and yeasts. nd: not detected. 


\section{DISCUSSION}

From the production of legume silage, such as soybeans, silages with fermentation characteristics different from those observed for standard plants for the ensiling process, such as corn, are expected. On the other hand, the quality of silages parameters, such as $\mathrm{pH}$; organic acids and ammonia-N on the dry matter contents, observed in the soybean silages can be consider as a good silage.

Values of ammonia-N ( $\mathrm{g} \mathrm{kg}^{-1}$ of total nitrogen) lower than 150.0 indicate good fermentation in legume silages according to Mahan and Chase (2003); therefore, the quality of the investigated silages can be considered as good. The ammonia$\mathrm{N}$ content increased from $28^{\text {th }}$ to $56^{\text {th }}$ day after ensiling observed to control and I silages probably due the further protein degradation observed to these silages or by overheating of the silo by Maillard reactions (Pigurina, 1991). The lower average values of ammonia-N contents observed to $\mathrm{I}+\mathrm{M}$ and $\mathrm{M}$ silages can be associated to effect of inoculant and molasses powder to control the undesirable fermentations by inclusion of BAL and carbohydrates in the silage production process. In fact, the addition of inoculant in plants before ensiling is a technique recommended mainly to legume silages, because of the undesirable fermentations suffered by these species due to their high buffering capacity (Nussio et al., 2002; Reis et al., 2004).

The linear increase of lactic acid observed to all silages evaluated might be a consequence from the predominance of lactic acid bacteria, despite the linear increase of acetic acid throughout the fermentation period (Muck, 1996). On the other hand, the higher values of lactic, acetic and butyric acids contents observed on the $56^{\text {th }}$ day of fermentation in the control silages may have occurred because the development of the BAL was not sufficient to inhibit the development of ENT and CL in these silages.

To the silages with $\mathrm{I}+\mathrm{M}$ and $\mathrm{M}$ were observed higher average values to lactic acid/acetic acid, probably because of the effect of inoculant and molasses by add BAL and carbohydrates in the silage process, improving their fermentative profile. In fact, inoculants with homolactic bacteria improves the lactic acid contents of these silages and promotes fast reduction their
$\mathrm{pH}$ values maintenting the quality of the silage (Kung et al., 2003). Considering that the production of acetic acid in silages is indicative of the development of enterobacteria that may occur in the initial phase of the fermentation process, the acetic acids contents in all the silages evaluated can be consider low and these values are below the maximum considered by Paulino et al. (2009), equal $2 \%$ on the dry matter, to silages with good quality.

The higher reduction of $\mathrm{pH}$ values in the first 10 days of fermentation estimated to $\mathrm{I}+\mathrm{M}$, and $\mathrm{M}$ silages can be associated to fast development of BAL and the lower ammonia-N average values observed to these silages. The same explanation can be used to higher reduction values estimated between $11^{\text {th }}$ and $56^{\text {th }}$ days of fermentation to $\mathrm{I}+\mathrm{M}$ silages.

The decline in $\mathrm{pH}$ observed in this study might be regarded as low, which might be due to low water-soluble carbohydrate content and low epiphytic population of $\mathrm{LAB}$ in soybean plants before ensiling. The $\mathrm{pH}$ values are like that established by Mahana and Chase (2003) for legume silages (4.5), which stabilise at higher $\mathrm{pH}$ values. The lower $\mathrm{pH}$ estimated values observed to $\mathrm{I}+\mathrm{M}$ and $\mathrm{M}$ silages, at the 56th fermentation day, might be the lactic acid production by advantage of lactic acid bacteria these silages. Pereira et al. (2007) assessed the fermentation profile and dry matter recovery of soybean silages treated with inoculant and powdered molasses also found lower $\mathrm{pH}$ values in silages treated with these additives.

Our results agree with those of Lima et al. (2009), who observed lower $\mathrm{pH}$ and ammonia-N values as well as higher lactic acid values in soybean mixed with sorghum silages treated with microbial inoculants and molasses.

The largest LAB population equal 9.15log CFU $\mathrm{g}^{-1}$ of silage at 28 days of fermentation in I silages can be associated to the contribution of homolactic bacteria presents in the inoculant. In addition, the microorganisms contents observed in the silages evaluated, such as highest value to ENT population reached on the $1^{\text {st }}$ fermentation day in control silage, and its presence could not be detected in any silage from the $7^{\text {th }}$ fermentation day onwards; CL detected only in the $1^{\text {st }}$ fermentation day for control and I silage; 
moulds and yeast populations ranged from 10 to $10^{3} \log \mathrm{CFU} \mathrm{g}{ }^{-1}$ of silage, can be explained for the reduction of clostridia fermentation for the inoculation with homolactic BAL, maximizing the utilization of carbohydrates in the silage.

The presence of MY populations observed to all silages in the fermentative days evaluated can be explained to capacity of the yeasts grow in low $\mathrm{pH}$ conditions. In fact, important spoilage microorganisms possible to occur during the ensiling process are molds, which arise if silage is exposed to air (Wilhelm and Wurm, 1999). Their presence must be inhibited by a low $\mathrm{pH}$ and anaerobic conditions that can promotes a more rapid decline in silage $\mathrm{pH}$ and blocks the proteolytic enzymes from the plant (Enterobacteria and Clostridium), which improves the silage quality (Tomich et al., 2004). Also yeasts, facultative anaerobic, ferment sugars under anaerobic conditions mainly to $\mathrm{CO}_{2}$ and ethanol (Schlegel, 1987 and McDonald et al., 1991, cited by Oude Elferink et al., 2001, which limits the availability of sugar for the use in lactic acid fermentation (Randby et al., 1999, cited by Oude Elferink et al., 2001.

According to Pahlow et al. (2003), the development of MY is associated the oxygen presence at the beginning of ensiling process. In addition, with the advancement of fermentative period the oxygen used in the silage promote the reduction of these microorganisms. This fact can be explained by capacity of developing of aerobic microorganisms, as well as facultative anaerobic bacteria, at higher $\mathrm{pH}$ conditions in the medium, at the beginning of the ensiling process. As $\mathrm{pH}$ decreases and oxygen is consumed (by aerobic microorganisms and by plant cells), acidic tolerant anaerobic and anaerobic bacteria capable of developing in a medium with lower oxidation potential replace the previous ones (Pahlow et al., 2003). In this way, possibly due to the rapid fall of $\mathrm{pH}$, an inhibition of the action of proteolytic bacteria occurs, leading to a lower production of ammonia-N. Proteolysis during ensiling started with the action of proteolytic enzymes, which resulted in the formation of peptides and amino acids. In addition, bacteria of the genus Clostridium and Enterobacteria, which develop in environments with high $\mathrm{pH}$ (Pahlow et al., 2003). Thus, reducing the $\mathrm{pH}$ of the silage by inoculation may have reduced the development of these microorganisms, thereby reducing proteolysis.

The population of $\mathrm{LAB}$ found in the soybean plant was $4.1 \log \mathrm{CFU} \mathrm{g} \mathrm{g}^{-1}$ of forage, and thus, it was lower than the value of $10^{5}$ recommended by Muck (1991) for fresh forage as the minimum required to avoid significant losses throughout fermentation as a function of lactic fermentation of silage. However, the higher value of $9.15 \mathrm{log}$ CFU $\mathrm{g}^{-1}$ of the silage LAB population observed at 28 days of fermentation in inoculated silage was probably due to the contribution of LAB present in the inoculant. Although, silage with inoculant and molasses should exhibit a larger population of these microorganisms, which was only observed on the $7^{\text {th }}$ fermentation day.

Pereira et al. (2007) assessed microbial populations in silages of three soybean varieties treated with inoculant observed that the inoculated silages exhibited a higher LAB population $(\mathrm{P}<0.05)$ than control silages; this effect was attributed to the presence of soluble sugars associated with the inoculant that stimulated lactic fermentation and, thus, a greater growth of lactic acid bacteria in the silage.

The lack of detection of ENT in all silages from the $7^{\text {th }}$ fermentation day onwards might be due to the $\mathrm{pH}$ reduction in silages (Figure 1) probably because these microorganisms require higher $\mathrm{pH}$ ranges to develop (McDonald et al., 1991). According to these authors, a decrease of ENT improves the quality of silages because this class of bacteria ferments sugars, giving rise to acetic acid and carbonic gas; thus, they increase the dry matter and energy loss as well as the formation of ammonium from protein structures, which is relevant because ammonia inhibits the voluntary intake by animals.

The presence of moulds and yeasts (MY) throughout the fermentation periods in all silages also might indicate that the amount of organic acids produced was not enough to inhibit the growth of these organisms (Weinberg et al., 1993). Alternatively, and despite the quick and efficient production of lactic acid and $\mathrm{pH}$ reduction due to the inoculation of homofermentative $\mathrm{LAB}$, the development of yeast populations continued because they can grow in low $\mathrm{pH}$ conditions. 
According to Blount et al. (2006), the watersoluble carbohydrates content in legume plants, required for an appropriate fermentation, is low. Therefore, the addition of an immediately fermentable sugar source, such as powdered molasses, and, or the use of microbial inoculants could contribute to adequate fermentation when soybean plants are ensiled.

If the carbohydrate concentration is sufficiently high, the conditions are more favorable for the establishment and growth of homofermentative bacteria, allowing forage conservation in the acid environment due to the production of lactic acid. In such a situation, good quality silage can be obtained even with plants with low dry matter content. On the other hand, when water soluble carbohydrates values are low, only good quality silages are produced when the dry matter content is high by activity of Clostridium bacteria is inhibited by reducing the osmotic pressure (Silva et al., 2011). In this trial, the soybean plants showed average values to dry matter before ensiling of $26.5 \%$ and these values are close to the values of $25.5 \%$ considered by (McDonald et al., 1991) as a necessary condition for the losses by effluent in the silo to be minimized and, therefore, the maintenance of the nutrients of their silages, producing a silage with quality.

\section{CONCLUSION}

The addition of microbial inoculants and powdered molasses during soybean ensiling improve the fermentation profile of silages, resulting in lower values of $\mathrm{pH}$, ammonia-N and acetic and butyric acids contents, producing a good silage.

\section{ACKNOWLEDGMENTS}

The authors would like to thank CNPq, CAPES and INCT/CA for the financial support.

\section{REFERENCES}

BRAZIL. Ministry of Agriculture, Livestock and Food Supply. Agribusiness projections. Brasília, $8^{\text {th }}$ edition, 2017.

BLOUNT, A.R.S.; WRIGHT, D.L.; SPRENKEL, R.K. et al. Forage soybeans for grazing, hay and silage. University of Florida, IFAS Extensión, 2006. Available in: <http://edis.ifas.ufl.edu/AG184>. Accessed in 30 Jan. 2016.
BOLSEN, K.K.; LIN, C.; BRENT, B.E. et al. Effect of silage additives on the microbial succession and fermentation process of alfafa and corn silage. J. Dairy Sci., v.75, p.3066-3083, 1992.

CONAB, NACIONAL COMPANY OF SUPPLY. Brazilian grain crop. v. 1, n.3 (2013), Brasília: Conab, 2013, v. Mensal. Available in: <http://www.conab.gov.br>. Accessed in: 29 Jan. 2016.

HRISTOV, A.N.; McALLISTER, T.A. Effect of inoculants on whole-crop barley silage fermentation and dry matter disappearance in situ. J. Anim. Sci., v.80, p.510-516, 2002.

KUNG JR., L.; STOKES, M.R.; LIN, C.J. Silage additives. In: SILAGE SCIENCE AND TECHNOLOGY, 42., 2003, Madison. Proceedings... Madison: American Society of Agronomy, Crop Science Society of America, Soil Science Society of America, 2003. p.251304.

LIMA, R.; LOURENÇO, M.; DÍAZ, R.F. et. al. Effect of combined ensiling of sorghum and soybean with or without molasses and lactobacilli on silage quality and in vitro rumen fermentation. Anim. Feed Sci. Technol., v.155, p.122-131, 2009.

MAHANA, B.; CHASE, L.E. Practical application and solution to silage problems. In: SILAGE SCIENCE AND TECHNOLOGY, 42., 2003. Madison. Proceedings... Madison: ASCSSA-SSSA, Agronomy, 2003. P.31-93.

McDONALD, P.; HENDERSON, A.R.; HERON, S.J.E. The biochemistry of silage. 2.ed. Aberystwyth: Chalcombe Publications, 1991. 340p.

MUCK, R. E. Silage fermentation. In: ZEIKUS, J.G.; JOHNSON, E.A. Mixed cultures in biotechnology. New York: McGrow Hill Inc., 1991. Chap.7, p.171-204.

MUCK, R.E. Inoculant of silage and its effects on silage quality. In: INFORMATIONAL CONFERENCE WITH DAIRY AND FORAGE INDUSTRIES. 1996. Wisconsin. Proceedings... Wisconsin: US Dairy Forage Research,1996. p.43-52.

MUÑOZ, A.; HOLT, E.; WEAVER, R. Yield and quality of soybean hay as influenced by stage of growth and plant density. Agron. J., v.75, p.147-149, 1983. 
NUSSIO, L.G.; PAZIANI, S.F.; NUSSIO, C.M.B. Tropical forages ensiling. In: ANUAL MEETING AT BRAZILIAN SOCIETY OF ANIMAL SCIENCE, 39., 2002. Recife. Proceedings... Recife: [SBZ], 2002.

OUDE ELFERINK, S.J.W.H.; KROONEMAN, J.; GOTTSCHAL, J.C. Anaerobic conversion of lactic acid to acetic acid and 1,2-propanediol by Lactobacillus buchneri. Appl. Environ. Microbiol., v.67, p.125-132, 2001.

PAHLOW, G.; R.E. MUCK; F. DRIEHUIS. Microbiology of ensiling. In: SILAGE SCIENCE AND TECHNOLOGY, 42., 2003, Madison. Proceedings... Madison: ASCSSA-SSSA, Agronomy, 2003. p.31-93.

PAULINO, V.T.; FERRARI JÚNIOR, E.; POSSENTI, R.A.; LUCENAS, T.L. Silage of forage peanut (Arachis pintoi cv. Belmonte) with different additives. Braz. J. Vet. Res. Anim. Sci., v.66, p.33-43, 2009.

PEREIRA, O.G.; ROSA, L.O.; SANTOS, E.M. Fermentative profile of soybean treated with molasses and microbial inoculant. In: INTERNATIONAL GRASSLAND CONGRESS, 21., 2008 / INTERNATIONAL RANGELAND CONGRESS, 7., 2008, Hohhot. Proceedings. Guangdong: Guangdong People's Publishing House, 2008. p.662-662.

PEREIRA, O.G.; SANTOS, E.M.; ROSA, L.O.; PEREIRA, D.H. Fermentative profile of soybean treated with molasses and microbial inoculant. In: ANUAL MEETING AT BRAZILIAN SOCIETY OF ANIMAL SCIENCE, 2007, Jaboticabal. Proceedings... Jaboticabal: [SBZ], 2007.

PIGURINA, F. Factores que afectan em valor nutritivo y la calidad de fermentacion de ensilajes. In: _. Pasturas y producción animal de áreas organaderia intensiva. Montevideo: Instituto Nacional de Investigación Agropecuaria, 1991. p.77-92. (Serie Tecnica, $15)$.

RANDBY A.T.; SELMER-OLSEN I.; BAEVRE L. Effect of ethanol in feed on milk flavor and chemical composition. J. Dairy Sci., v.82, p.420428, 1999.
RANJIT, N. K.; KUNG JR, L. The effect of Lactobacillus buchneri, Lactobacillus plantarum, or a chemical preservative on the fermentation and aerobic stability of corn silage. J. Dairy Sci., v.83, p.526-535, 2000.

REIS, R.A.; BERNARDES, T.F.; AMARAL, R.C. Nitrogen components in marandu-grasses (Brachiaria brizantha cv marandu) ensiling with pelleted citric pulp. In: ANUAL MEETING AT BRAZILIAN SOCIETY OF ANIMAL SCIENCE, 41., 2004, Campo Grande. Proceedings... Campo Grande: SBZ, 2004.

SCHLEGEL, H.G. 1987. General Microbiology. 6th ed. Cambridge University Press, Cambridge, UK.

SANTOS, E.M.; PEREIRA, O.G.; GARCIA, R. et al. Microbial populations, fermentative profile and chemical composition of signalgrass silages at different regrowth ages. R. Bras. Zootec. vol.40, no.4, 2011.

SILVA, D.J.; QUEIROZ, A.C. Análise de alimentos: métodos químicos e biológicos . 3.ed. Viçosa: UFV, 2002. 235p.

SILVA T.C.; DANTAS, P.A.S.; DÓREA, J.R.R. et. al. Microbial populations, fermentation profile and chemical composition of elephant grass silages with jackfruit. Arch. Anim. Sci., v.60, p.247-255, 2011.

SYSTEM for statistical analyzes - SAEG. Version 9.1. Viçosa: UFV/Fundação Arthur Bernardes, 2007. 142p.

TOMICH, T.R.; RODRIGUES, J.A.S.; TOMICH, R.G.P. et al. Potencial forrageiro de híbridos de sorgo com capim-sudão. Braz. J. Vet. Anim. Sci., v.56, p.258-263, 2004.

UNDERSANDEN, D.; JAREK, K.; ANDERSON, T. et. al. A guide to making soybean silage. Plant Management Network, 2007. Available in: <http://www.rpcm.wisc.edu/Portals/O/Blog/Files /17/361/Soybean Silage.pdf $>$. Accessed in: 29 Jan. 2016.

WEINBERG, Z.G.; ASHBELL, G.; HEN, Y.; AZRIELI, A. The effect of applying lactic acid bacteria at ensiling on the aerobic stability of silages. J. Appl. Bacteriol., v.75, p.512-518, 1993.

WILHELM, H.; WURM, K. Futterkonservierung und - qualitat. Verlag Graz: Leopold Stocker, 1999. 141p. 